\title{
Natural and Fukushima-derived radioactivity in macroalgae and mussels along the Japanese shoreline
}

\author{
Z. Baumann ${ }^{1}$, N. Casacuberta ${ }^{2,}$, , H. Baumann ${ }^{1}$, P. Masqué ${ }^{2}$, and N. S. Fisher ${ }^{1}$ \\ ${ }^{1}$ School of Marine and Atmospheric Sciences, Stony Brook University, Stony Brook, NY 11794-5000, USA \\ ${ }^{2}$ Institut de Ciència i Tecnologia Ambientals \& Departament de Física, Universitat Autònoma de Barcelona, 08193, \\ Bellaterra, Spain \\ * now at: ETH-Zurich, Laboratory of Ion Beam Physics, HPK G26, Schafmattstrasse 20, 8093 Zurich, Switzerland \\ Correspondence to: Z. Baumann (zofia.baumann@stonybrook.edu)
}

Received: 1 January 2013 - Published in Biogeosciences Discuss.: 13 February 2013

Revised: 8 May 2013 - Accepted: 14 May 2013 - Published: 13 June 2013

\begin{abstract}
Following the failure of the nuclear power plant in Fukushima Prefecture in March 2011, peer-reviewed publications describing radioactivity levels in organisms inhabiting coastal environments are scarce. This paper reports on elevated levels of ${ }^{134} \mathrm{Cs}$ and ${ }^{137} \mathrm{Cs}$ in macroalgae and mussels (up to $\sim 800 \mathrm{~Bq} \mathrm{~kg}^{-1}$ dry wt.) in June 2011 . Cs concentrations in biota sampled in early June 2011 were higher in areas south of Fukushima than sampled in the last third of the month north of Fukushima. Activity concentrations from ${ }^{134+137} \mathrm{Cs}$ in organisms south of Fukushima were comparable to or lower than those from the naturally occurring ${ }^{40} \mathrm{~K}$ in the same samples. While ${ }^{210} \mathrm{~Pb}$ and ${ }^{210} \mathrm{Po}$ concentrations were generally lower than these other radionuclides, ${ }^{210} \mathrm{Po}$ as an $\alpha$-emitter is more significant from a radiological viewpoint than $\gamma$-emitters as it can inflict greater biological damage. By applying known bioconcentration factors of Cs in biota, measured biota concentrations of Cs were also used to estimate Cs concentrations in coastal seawater to be in the range of $10^{2}-10^{3} \mathrm{~Bq} \mathrm{~m}^{-3}$. These estimates show that, 3 months after the accident and maximal release of radioactive Cs, levels of Cs persisted in coastal waters, although at levels that were two orders of magnitude lower than at the time of release. These June coastal seawater Cs levels were four orders of magnitude above Cs concentrations off Japan prior to the Fukushima disaster.
\end{abstract}

\section{Introduction}

Following the devastation caused by the earthquake and tsunami on 11 March 2011, the Japanese public was anxious regarding radioactivity release from the damaged Fukushima Daiichi nuclear power plant (NPP). Radioactivity released onto land led to contamination in vegetable produce, dairy, and meat products, and similarly release into the coastal ocean led to contamination of seafood. Recognizing public concerns, the Ministry of Agriculture, Forestry and Fisheries (MAFF) initiated a monitoring program that set allowable radioactivity levels in seafood to $500 \mathrm{~Bq} \mathrm{~kg}^{-1}$ wet weight (wet wt., later lowered to $100 \mathrm{~Bq} \mathrm{~kg}^{-1}$ wet weight) for radioactive cesium (i.e., sum of ${ }^{134} \mathrm{Cs}$ and ${ }^{137} \mathrm{Cs}$ ) (MAFF). Post-Fukushima academic studies have either attempted to predict consequences of the fallout for human and animal health (Kryshev and Sazykina, 2011; Garnier-Laplace et al., 2011; Murakami and Oki, 2012) or focused on estimating the quantities of released radioactivity and their atmospheric and oceanic dissipation (Buesseler et al., 2011, 2012; Tsumune et al., 2011; Yoshida and Kanda, 2012; Masson et al., 2011). However, peer-reviewed studies of radioactive concentrations in post-Fukushima marine animals and plants remain surprisingly scarce. Apart from detailed radioactivity measurements in small fish and crustaceans collected offshore during an international survey in June 2011 (Buesseler et al., 2012), peer-reviewed reports of radioactivity in economically important coastal organisms (e.g., macroalgae, bivalves) are missing. However, TEPCO (Tokyo Electric Power Company), MEXT (Ministry of Education, Culture, 


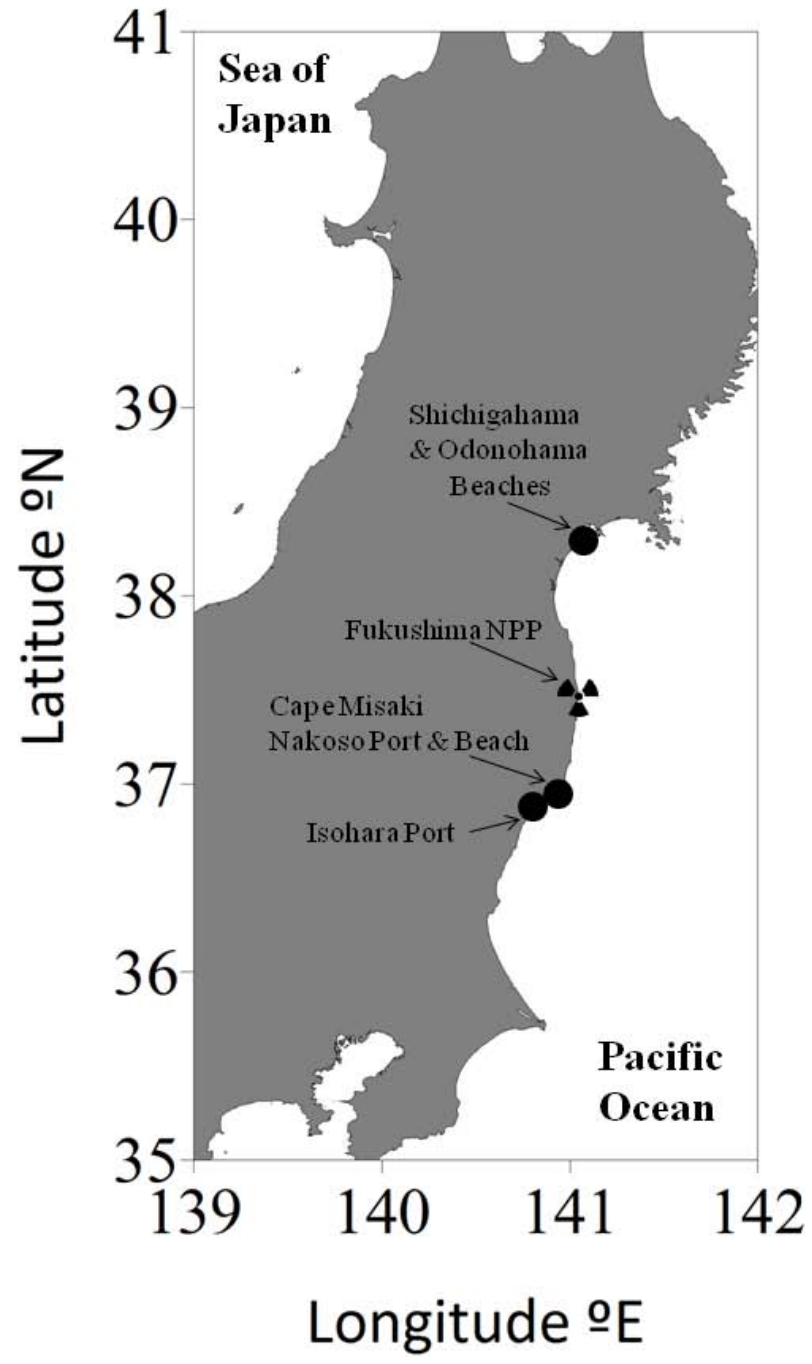

Fig. 1. Sampling locations for mussels and macroalgae along the east coast of Honshu Island of Japan.

Sports, Science, and Technology) and MAFF have used the Internet as an outlet for continuous publication of radioactivity measurements in sediments, water and biota. While there is undeniably a value to a stream of data published on the web page, this approach is missing key information on methodology and therefore missing quality assurance (MEXT; MAFF; TEPCO, 2013).

The goal of this study was to quantify June 2011 levels of Fukushima-derived $\gamma$-emitting cesium isotopes (i.e., ${ }^{134} \mathrm{Cs}$, ${ }^{137} \mathrm{Cs}$ ) in mussels and macroalgae, collected from coastal locations north and south of the Fukushima NPP (Fig. 1). A second goal was to put these levels in the context of naturally occurring radioactivity due to $\gamma$ - and $\beta$-emitting potassium $\left({ }^{40} \mathrm{~K}\right)$ and ${ }^{210} \mathrm{~Pb}$ and $\alpha$-emitting polonium $\left({ }^{210} \mathrm{Po}\right)$ isotopes present in these organisms, which is directly relevant to assessing any increased radioactive dose for seafood consumers.

\section{Material and methods}

\subsection{Sample collection}

Samples of green (Ulva sp.) and brown (species were not identified) macroalgae as well as mussels (Mytilus galloprovincialis; average shell length $45.0 \pm 3.8 \mathrm{~mm}$ ) were collected by hand along several Pacific beaches south (2 June 2011) and north of Fukushima NPP (21 June 2011) (Fig. 1). Collection times were different for the northern and southern locations due to logistical capabilities. Southern sampling sites, i.e., Isohara port $\left(36.81^{\circ} \mathrm{N}, 140.76^{\circ} \mathrm{E}\right)$, Nakoso beach and port $\left(36.86^{\circ} \mathrm{N}, 140.79^{\circ} \mathrm{E}\right.$ and $36.83^{\circ} \mathrm{N}$, $140.80^{\circ} \mathrm{E}$, respectively), and the Cape Misaki $\left(36.94^{\circ} \mathrm{N}\right.$, $140.91^{\circ} \mathrm{E}$ ), were approximately $70 \mathrm{~km}$ south of Fukushima $\mathrm{NPP}$, while northern sites, Odonohama $\left(38.28^{\circ} \mathrm{N}, 141.05^{\circ} \mathrm{E}\right)$ and Shichigahama $\left(38.29^{\circ} \mathrm{N}, 141.07^{\circ} \mathrm{E}\right)$ beaches, were approximately $30 \mathrm{~km}$ north of Fukushima NPP. Samples were sealed in plastic bags and shipped to Stony Brook University in New York in coolers with dry ice $\left(-50^{\circ} \mathrm{C}\right)$.

\subsection{Sample preparation}

In the laboratory, mussel shells were separated from soft tissue, since only the latter was assumed to have accumulated radioactive $\mathrm{Cs}$ (Ke et al., 2000). Mussel tissue and macroalgae were placed into individual plastic containers and stored at $-80^{\circ} \mathrm{C}$ for $24 \mathrm{~h}$ prior to freeze-drying. All samples were then placed inside fast-freeze flasks and connected to a Labconco FreeZone Benchtop Freeze Dry System that was cooled to $-52{ }^{\circ} \mathrm{C}$, and pressurized to $0.12 \mathrm{mbar}$ (Buesseler et al., 2012). After freeze-drying, samples were ground with a ceramic mortar and pestle to obtain homogeneously distributed samples that varied in dry weight (dry wt.) from 3.1 to $79.1 \mathrm{~g}$. Samples were stored in straightside polypropylene $120 \mathrm{~mL}$ jars (Nalgene), which had been efficiency-calibrated to their specific geometry.

\section{$2.3 \quad{ }^{134} \mathrm{Cs},{ }^{137} \mathrm{Cs}$ and ${ }^{40} \mathrm{~K}$ analysis}

We used a planar, low energy germanium detector (Canberra model GLP 3830) and Genie 2000 software (Canberra) to measure and analyze the spectrum of $\gamma$ emissions in our samples. Average counting time was $27 \mathrm{~h}$, and the average counting uncertainties were $4 \%$ for ${ }^{134} \mathrm{Cs}$ and ${ }^{137} \mathrm{Cs}$, and $8 \%$ for ${ }^{40} \mathrm{~K}$. The detector efficiency was determined as previously described by Buesseler et al. (2012) for individual radioisotopes with varying geometries as follows: $1.7-3.5 \%$ for ${ }^{134} \mathrm{Cs}$ (at $604.7 \mathrm{keV}$ peak), $1.6-3.2 \%$ for ${ }^{137} \mathrm{Cs}$ (at $661.7 \mathrm{keV}$ peak), and $0.8-1.7 \%$ for ${ }^{40} \mathrm{~K}$ (at $1461 \mathrm{keV}$ peak). Calculations of ${ }^{134} \mathrm{Cs}$, ${ }^{137} \mathrm{Cs}$, and ${ }^{40} \mathrm{~K}$ concentrations in the samples assumed negligible self-absorption of $\gamma$ rays for these isotopes, given that they all emit at energies $>200 \mathrm{keV}$ (Hurtado et al., 2007). Correction for coincidence summing was omitted as a low efficiency planar detector was used for sample analyses. Measured ${ }^{134} \mathrm{Cs}$ and ${ }^{137} \mathrm{Cs}$ were decay-corrected to 
Table 1. Dry-weight-based concentrations of ${ }^{134} \mathrm{Cs},{ }^{137} \mathrm{Cs},{ }^{40} \mathrm{~K}$ and ${ }^{210} \mathrm{Po}$ in macroalgae and mussels sampled in June 2011 along the east coast of Japan. Activities were decay-corrected to the date of sample collection, except for ${ }^{40} \mathrm{~K}$ given its very long half-life $\left(1.25 \times 10^{9} \mathrm{yr}\right)$. $\sigma$ is the propagated counting error $\left(\mathrm{Bq} \mathrm{kg}^{-1}\right)$.

\begin{tabular}{|c|c|c|c|c|c|c|c|c|c|c|c|c|c|c|c|c|}
\hline $\begin{array}{l}\text { Sample } \\
\text { type }\end{array}$ & NPP* & Location & $\begin{array}{l}\text { Lat. } \\
{ }^{\circ} \mathrm{N}\end{array}$ & $\begin{array}{l}\text { Long. } \\
{ }^{\circ} \mathrm{E}\end{array}$ & $\begin{array}{c}{ }^{134} \mathrm{Cs} \\
\mathrm{Bq} \mathrm{kg}^{-1}\end{array}$ & $\pm \sigma$ & $\begin{array}{c}{ }^{137} \mathrm{Cs} \\
\mathrm{Bq} \mathrm{kg}^{-1}\end{array}$ & $\pm \sigma$ & ${ }^{134} \mathrm{Cs}:{ }^{137} \mathrm{Cs}$ & $\pm \sigma$ & $\begin{array}{c}{ }^{210} \mathrm{Po} \\
\mathrm{Bq} \mathrm{kg}^{-1}\end{array}$ & $\pm \sigma$ & $\begin{array}{c}{ }^{210} \mathrm{~Pb} \\
\mathrm{~Bq} \mathrm{~kg}^{-1}\end{array}$ & $\pm \sigma$ & $\begin{array}{c}{ }^{40} \mathrm{~K} \\
\mathrm{~Bq} \mathrm{~kg}^{-1}\end{array}$ & $\pm \sigma$ \\
\hline \multirow[t]{5}{*}{$\begin{array}{l}\text { Brown } \\
\text { algae }\end{array}$} & $\mathrm{N}$ & $\begin{array}{l}\text { Shichigahama } \\
\text { Beach }\end{array}$ & 38.29 & 141.07 & 108 & 5.1 & 103 & 5.1 & 1.05 & 0.07 & 16.3 & 3.2 & 1.7 & 0.2 & 842 & 55 \\
\hline & & $\begin{array}{l}\text { Odonohama } \\
\text { Beach }\end{array}$ & 38.28 & 141.05 & 80 & 5.4 & 87 & 5.8 & 0.92 & 0.09 & 29.6 & 3.6 & 4.6 & 0.3 & 880 & 68 \\
\hline & & & & & 124 & 6.2 & 143 & 6.6 & 0.87 & 0.06 & 10.3 & 2.2 & 0.9 & 0.1 & 1189 & 73 \\
\hline & & & & & 127 & 4.4 & 152 & 4.8 & 0.83 & 0.04 & 23.7 & 4.4 & 8.3 & 0.4 & 1369 & 56 \\
\hline & $\mathrm{S}$ & Nakoso Port & 36.94 & 140.91 & 239 & 4.7 & 282 & 5.1 & 0.85 & 0.02 & 17.8 & 3.2 & 2.2 & 0.2 & 1296 & 44 \\
\hline \multirow[t]{3}{*}{$\begin{array}{l}\text { Green } \\
\text { algae }\end{array}$} & $\mathrm{N}$ & $\begin{array}{l}\text { Shichigahama } \\
\text { Beach }\end{array}$ & 38.29 & 141.07 & 66 & 5 & 84 & 4.9 & 0.78 & 0.07 & 18.1 & 2.7 & 5.1 & 0.4 & 511 & 52 \\
\hline & & $\begin{array}{l}\text { Odonohama } \\
\text { Beach }\end{array}$ & 38.28 & 141.05 & 60 & 2.2 & 73 & 2.4 & 0.82 & 0.04 & 115 & 6.9 & 5.4 & 0.3 & 509 & 26 \\
\hline & $\mathrm{S}$ & Cape Misaki & 36.94 & 140.91 & 369 & 5.1 & 435 & 5.6 & 0.85 & 0.02 & 272 & 21.7 & 8.8 & 0.5 & 426 & 24 \\
\hline \multirow[t]{3}{*}{ Mussels } & $\mathrm{N}$ & Odonohama Beach & 38.28 & 141.05 & 51 & 2.1 & 59 & 2.2 & 0.87 & 0.05 & 14.0 & 2.9 & 1.3 & 0.1 & 353 & 21 \\
\hline & $\mathrm{S}$ & Cape Misaki & 36.94 & 140.91 & 393 & 5.6 & 463 & 6.1 & 0.85 & 0.02 & 28.8 & 3.6 & 4.5 & 0.3 & 300 & 22 \\
\hline & & & & & 372 & 8.8 & 417 & 9.1 & 0.89 & 0.03 & 300 & 21 & 7.7 & 0.8 & 334 & 36 \\
\hline
\end{tabular}

* North (N) or south (S) relative to the Fukushima nuclear power plant (NPP)

the date of sample collection (taking into consideration their half-lives of 2.07 and $30.08 \mathrm{yr}$, respectively).

\subsection{Analyses of ${ }^{210} \mathrm{~Pb}$ and ${ }^{210} \mathrm{Po}$}

Small sub-samples $(0.5-1.0 \mathrm{~g})$ were spiked with known amounts of ${ }^{209} \mathrm{Po}(0.07 \mathrm{~Bq})$ and stable $\mathrm{Pb}(0.1 \mathrm{mg})$ as internal tracers of the radiochemical analysis. After the addition of tracers, sub-samples were acid-digested at $80-90{ }^{\circ} \mathrm{C}$ on a hot plate for $10-12 \mathrm{~h}$ using $65 \% \mathrm{HNO}_{3}(30-40 \mathrm{~mL})$ and a few drops of $\mathrm{H}_{2} \mathrm{O}_{2}$. Digested samples were filtered (Albet Quantitative Filter Paper ashless hardened DP 1507), non-digested residuals discarded, and samples reconstituted to $80 \mathrm{~mL}$ of $1 \mathrm{~N} \mathrm{HCl}$ after evaporation to dryness. Samples were heated to $70^{\circ} \mathrm{C}$ and ascorbic acid added to reduce $\mathrm{Fe}(\mathrm{III})$. The polonium isotopes were plated onto silver disks at $70^{\circ} \mathrm{C}$ for $8 \mathrm{~h}$ while stirring. Polonium emissions were counted by alpha particle spectrometry using silicon surface barrier and PIPS detectors (EG\&Ortec and Canberra). Upon plating and to assure the complete removal of polonium, the solutions were converted to $9 \mathrm{M} \mathrm{HCl}$ and passed through ion exchange columns (resin type Dowex 1X8, 100-200 mesh). Aliquots of each sample were taken before and after this step to determine the chemical yield for $\mathrm{Pb}$ by atomic absorption spectrometry. The solutions were re-spiked with ${ }^{209} \mathrm{Po}$ and stored for several months to attain sufficient growth of ${ }^{210} \mathrm{Po}$ from ${ }^{210} \mathrm{~Pb}$. After $4-6$ months, polonium isotopes were plated again onto silver disks and counted. Activities of both ${ }^{210} \mathrm{~Pb}$ and ${ }^{210} \mathrm{Po}$ at the time of sample collection were calculated after appropriate in-growth and decay corrections (Church et al., 2012).

\section{Results and discussion}

\subsection{Cesium in macroalgae and mussels}

All samples of post-Fukushima mussels and macroalgae contained ${ }^{134} \mathrm{Cs}$ (range: $51-393 \mathrm{~Bq} \mathrm{~kg}^{-1}$ dry wt.) and ${ }^{137} \mathrm{Cs}$ (range: $60-463 \mathrm{~Bq} \mathrm{~kg}^{-1}$ dry wt., Table 1). Measured ${ }^{137} \mathrm{Cs}$ concentrations in mussels and macroalgae prior to the Fukushima accident (background) were two to three orders of magnitude lower. For example, brown macroalgae collected off the Japanese coast in 2007-2008 had ${ }^{137} \mathrm{Cs}$ concentrations of $0.038-0.058 \mathrm{~Bq} \mathrm{~kg}^{-1}$ wet wt. (or $0.14-0.21 \mathrm{~Bq} \mathrm{~kg}^{-1} \mathrm{dw}$ assuming a wet/dry ratio of 0.27 ; Morita et al., 2010; Carvalho, 2011), and mussels (Mytilus edulis) collected from the south-western Korean Sea in 1988 had $0.04 \mathrm{~Bq} \mathrm{~kg}^{-1}$ dry wt. In the case of the shorter lived ${ }^{134} \mathrm{Cs}$ isotope (half-life $=2.07 \mathrm{yr}$ ), no other sources than the Fukushima accident could have produced the detected ${ }^{134} \mathrm{Cs}$ levels in mussels and algae. In addition, the ratio of ${ }^{134} \mathrm{Cs}:{ }^{137} \mathrm{Cs}$ in our macroalgae samples was approximately 1 (mean $\pm \mathrm{SD}=0.85 \pm 0.003$ and $0.88 \pm 0.10$ for the northern and southern sampling locations, respectively), consistent with ratios found in marine plankton (Buesseler et al., 2012) and similar to measured concentrations in the water following the radioactive discharge from the Fukushima NPP (Buesseler et al., 2011; MEXT; Aoyama et al., 2012).

Furthermore, our analyses revealed consistently lower radiocesium levels (i.e., the sum of ${ }^{137} \mathrm{Cs}$ and ${ }^{134} \mathrm{Cs}$ ) in samples from northern locations than those in the southern locations. However, even in the more contaminated southern locations none of the samples exceeded the $500 \mathrm{~Bq} \mathrm{~kg}^{-1}$ wet wt. safety limit. Differences in Cs contamination between the two regions were greatest for mussels. M. galloprovincialis from the site north of the Fukushima NPP contained 7.5 times less radiocesium than southern samples (north: mean 
Table 2. Estimates of ${ }^{134} \mathrm{Cs}$ and ${ }^{137} \mathrm{Cs}$ concentrations in coastal seawater at the locations north and south of the Fukushima NPP based on concentration factors (CFs; $\mathrm{L} \mathrm{kg}^{-1}$ ) derived from the literature (IAEA, 2004). Ranges are provided based on the maximum and minimum concentration values for the biota.

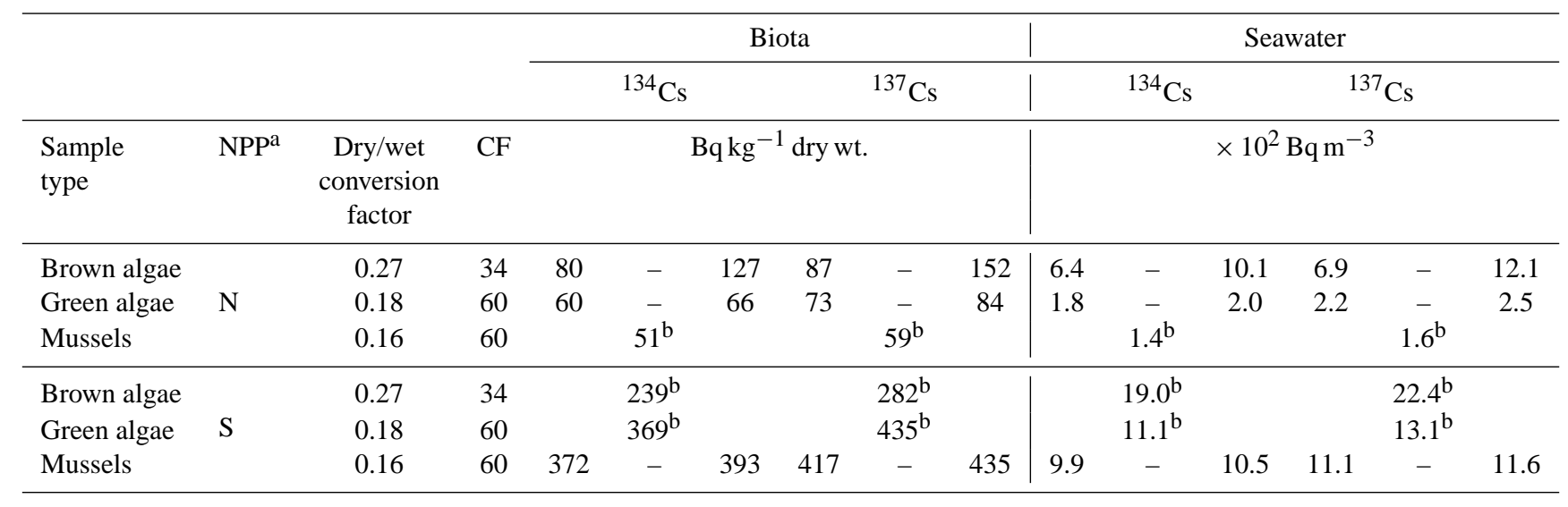

${ }^{a}$ North (N) or south (S) relative to the Fukushima nuclear power plant (NPP).

${ }^{\mathrm{b}}$ Indicates one value instead of a range when concentrations were available for only one sample.

of $110 \mathrm{~Bq} \mathrm{~kg}^{-1}$ dry wt.; south: mean of $822 \mathrm{~Bq} \mathrm{~kg}^{-1}$ dry wt.). Green macroalgae from northern locations contained on average $141 \mathrm{~Bq} \mathrm{~kg}^{-1}$ dry wt. of radiocesium, which was 5.7 times less than in the southern sample (804 $\mathrm{Bq} \mathrm{kg}^{-1}$ dry wt.), while brown macroalgae from the south contained approximately twice as much radiocesium as northern samples. Given that Cs uptake by macroalgae is proportional to the Cs concentrations in water (Gutknecht, 1965), we conclude that radiocesium levels were indeed higher in coastal waters south of Fukushima than in waters north of Fukushima at the time of sampling, likely due to the 19-day lag between sampling at these locations. Indeed, MEXT-online reports show $\mathrm{a} \sim 30 \%$ decline in ${ }^{137} \mathrm{Cs}$ seawater concentration at Dai-ichi within this time interval (i.e., 2-21 June 2011). Some of the difference in ${ }^{137} \mathrm{Cs}$ concentrations in biota collected at these two time points (i.e., the ${ }^{137} \mathrm{Cs}$ concentration difference between biota collected north on 21 June 2011 vs. those collected south on 2 June 2011) can be accounted for by the general decline of radioactivity at its discharge. Any further difference could be accounted for by the southward shore current along the Pacific coast of Honshu (Buesseler et al., 2012).

Cs concentrations in biota can be combined with published concentration factors $(\mathrm{CFs}$, i.e., the wet tissue to water activity ratio; $\mathrm{L} \mathrm{kg}^{-1}$ ) to estimate $\mathrm{Cs}$ concentrations in the water, assuming that the organisms were in equilibrium with ambient water (IAEA, 2004). Given that the biological half-lives of Cs in green and brown macroalgae and in mussels are 5-8 and 8 days, respectively (Gutknecht, 1965; Dahlgaard, 1981), it would appear that the assumption of equilibrium was met. However, for longer biological half-life values (e.g., as reported by Dahlgaard and Nolan, 1989, for Cs in M. edulis $-17.5 \mathrm{~d}$ ), assumption of equilibrium could lead to a greater error.
While CFs might be useful in approximating the concentration levels in the water, it is important to realize that these approximations come with an increased chance of error. For example, $\mathrm{CFs}$ of ${ }^{137} \mathrm{Cs}$ in various brown macroalgae varied up to $100 \%$ and in mollusks up to $67 \%$ in a study following radioactive waste disposal in Arctic seas (Fisher et al., 1999). The variation of $\mathrm{CF}$ values of ${ }^{137} \mathrm{Cs}$ in green mussels - Perna viridis - has been also related to body size, water pumping rate, and salinity (Ke et al., 2000). Due to observed variability of ${ }^{137} \mathrm{Cs} \mathrm{CFs}$ in algae and mussels, which however is smaller for an individual species, estimates of ${ }^{137} \mathrm{Cs}$ concentrations in seawater based on literature $\mathrm{CFs}$ are therefore expected to fall within fourfold of directly measured values.

By applying our measured Cs concentrations in mussels and using a Cs wet wt. CF for mussels as 60 (IAEA, 2004), we estimate total ambient radiocesium levels in northern and southern coastal sampling sites in June 2011 to have ranged from $2.9 \times 10^{2} \mathrm{~Bq} \mathrm{~m}^{-3}$ to $22.1 \times 10^{2} \mathrm{~Bq} \mathrm{~m}^{-3}$, respectively (Table 2). Estimates for seawater ${ }^{134} \mathrm{Cs}$ concentrations using our mussel concentrations of ${ }^{134} \mathrm{Cs}$ were $1.4 \times 10^{2}$ north of Fukushima NPP and $9.9 \times 10^{2}$ $10.5 \times 10^{2} \mathrm{~Bq} \mathrm{~m}^{-3}$ south of Fukushima NPP (Table 2). Reported CF values for green and brown algae are 60 and 34, respectively (IAEA, 2004). Using these CFs and a dry to wet weight ratio of 0.18 for green algae and 0.27 for brown algae (Carvalho, 2011), we estimate seawater ${ }^{134} \mathrm{Cs}$ concentrations of $1.8 \times 10^{2}-2.0 \times 10^{2} \mathrm{~Bq} \mathrm{~m}^{-3}$ north of Fukushima and $11 \times 10^{2} \mathrm{~Bq} \mathrm{~m}^{-3}$ south of Fukushima based on green algae measurements (Table 2). Brown-algae-based measurements estimated ${ }^{134} \mathrm{Cs}$ concentrations of $6.4 \times 10^{2}-10.1 \times 10^{2} \mathrm{~Bq} \mathrm{~m}^{-3}$ north of Fukushima and $19 \times 10^{2} \mathrm{~Bq} \mathrm{~m}^{-3}$ south of Fukushima (Table 2). Green-algae-based estimates of ${ }^{137} \mathrm{Cs}$ in seawater north of Fukushima are $2.2 \times 10^{2}-2.5 \times 10^{2} \mathrm{~Bq} \mathrm{~m}^{-3}$ and 
$13.1 \times 10^{2} \mathrm{~Bq} \mathrm{~m}^{-3}$ south of Fukushima, while brown-algaebased estimates of ${ }^{134} \mathrm{Cs}$ in seawater north of Fukushima are $6.9 \times 10^{2}-12.1 \times 10^{2} \mathrm{~Bq} \mathrm{~m}^{-3}$ and $22.4 \times 10^{2} \mathrm{~Bq} \mathrm{~m}^{-3}$ south of Fukushima (Table 2). These estimated ${ }^{137} \mathrm{Cs}$ concentrations in coastal seawater are generally about 2 orders of magnitude lower than the maximum ${ }^{137} \mathrm{Cs}$ concentrations recorded by TEPCO and presented by MEXT in mid-April at $30 \mathrm{~km}$ offshore Fukushima ( $\sim 200000 \mathrm{~Bq} \mathrm{~m}^{-3}$; Buesseler et al., 2011). It is practically impossible to relate our lower estimates at northern locations to those reported by MEXT, because ${ }^{137} \mathrm{Cs}$ detection limits declared in these reports were high (i.e., $6 \mathrm{BqL}^{-1}$ or $6 \times 10^{3} \mathrm{~Bq} \mathrm{~m}^{-3}$ ). Therefore, any $\mathrm{Cs}$ at concentrations lower than $6 \times 10^{3} \mathrm{~Bq} \mathrm{~m}^{-3}$ would not have been detected. ${ }^{137} \mathrm{Cs}$ concentrations predicted by us for the southern location on 2 June 2011 are at least sevenfold lower than $15 \times 10^{3} \mathrm{~Bq} \mathrm{~m}^{-3}$ reported online for seawater collected on 2 June 2011 near our sampling site (MEXT).

${ }^{134} \mathrm{Cs}$ concentrations measured in coastal seawater Onahama (Aoyama et al., 2012), near the southern sampling site in the present study, show up to threefold higher than the maximum CF-estimated values in the present study (Table 2). This agreement between our CF-estimation of seawater Cs and an actual measurement is consistent with an up to fourfold error (see above).

\section{2 ${ }^{40} \mathrm{~K},{ }^{210} \mathrm{~Pb}$ and ${ }^{210} \mathrm{Po}$ in macroalgae and mussels}

Naturally occurring radioisotopes ${ }^{40} \mathrm{~K},{ }^{210} \mathrm{~Pb}$ and ${ }^{210} \mathrm{Po}$ were detected for all samples. Highest concentrations of ${ }^{40} \mathrm{~K}$ were present in brown macroalgae (i.e., $842-$ $1369 \mathrm{~Bq} \mathrm{~kg}^{-1}$ dry wt.; Table 1), lower in green macroalgae (i.e., $426-511 \mathrm{~Bq} \mathrm{~kg}^{-1}$ dry wt.; Table 1), and in lowest in mussel soft tissue (300-353 $\mathrm{Bq} \mathrm{kg}^{-1}$ dry wt.; Table 1). Concentrations of ${ }^{210} \mathrm{~Pb}$ varied by an order of magnitude for brown algae $\left(0.9 \pm 0.10-8.3 \pm 0.40 \mathrm{~Bq} \mathrm{~kg}^{-1}\right.$ dry wt.; Table 1), but were similar for green algae $(5.1 \pm 0.36-$ $8.8 \pm 0.48 \mathrm{~Bq} \mathrm{~kg}^{-1}$ dry wt.; Table 1$) .{ }^{210} \mathrm{~Pb}$ in mussels varied by sixfold (Table 1). Concentrations of ${ }^{210} \mathrm{Po}$ were similar among brown algae samples and ranged from 10 to $30 \mathrm{~Bq} \mathrm{~kg}^{-1}$ dry wt. with an average of 19.5 $\pm 7.4 \mathrm{~Bq} \mathrm{~kg}^{-1}$ dry wt. (Table 1), but they were variable among the green algae and mussels. ${ }^{210} \mathrm{Po}$ concentration in green algae ranged from 18.1 to $272 \mathrm{~Bq} \mathrm{~kg}^{-1}$ dry wt., and from 14.0 to $300 \mathrm{~Bq} \mathrm{~kg}^{-1}$ dry wt. for mussels.

The variability in the ${ }^{40} \mathrm{~K}$ and ${ }^{210}$ Po levels for brown macroalgae (Table 1) is not unusual (Thompson et al., 1982; Uğur et al., 2002; Goddard and Jupp, 2001). Thompson et al. (1982) showed that for just one species of a brown macroalgae, Fucus vesiculosus, collected from the Irish Sea, ${ }^{40} \mathrm{~K}$ concentrations varied twofold. Another study showed that ${ }^{40} \mathrm{~K}$ concentrations can vary within algal divisions (Goddard and Jupp, 2001). In that study ${ }^{40} \mathrm{~K}$ concentrations showed a 44 -fold variation and ranged from 100 to $4400 \mathrm{~Bq} \mathrm{~kg}^{-1}$ dry wt. in green algae, and 125 $5400 \mathrm{~Bq} \mathrm{~kg}^{-1}$ dry wt. in brown algae (Goddard and Jupp,
2001). Published ${ }^{210}$ Po concentrations for green algae are scarce, but one study reported ${ }^{210} \mathrm{Po}$ concentration of $15 \mathrm{~Bq} \mathrm{~kg}^{-1}$ dry wt., which falls within the range of ${ }^{210} \mathrm{Po}$ concentration in green algae in this study (Carvalho, 2011). As in the present study, variability for ${ }^{210}$ Po concentrations in mussels has been reported. For example, ${ }^{210}$ Po concentrations showed 26-fold (52-1300 $\mathrm{Bq} \mathrm{kg}^{-1}$ dry wt.) variation for Mytilus galloprovincialis from various coastal locations of the Aegean Sea (Uğur et al., 2002). Wildgust et al. (1998) suggested that variation of ${ }^{210} \mathrm{Po}$ concentrations in organisms could be linked to environmental conditions such as salinity or temperature, and to biological parameters such as the reproductive cycle phase. The ratios of ${ }^{210} \mathrm{Po}:{ }^{210} \mathrm{~Pb}$ for green and brown macroalgae fit within the range of previously reported ratios, but for mussels ${ }^{210} \mathrm{Po}:{ }^{210} \mathrm{~Pb}$ ratios are lower in this study (Carvalho, 2011).

From a human-health perspective, it is important to assess levels of natural radionuclides such as ${ }^{40} \mathrm{~K},{ }^{210} \mathrm{Po}$ and ${ }^{210} \mathrm{~Pb}$ as these radionuclides are always present in seafood. Because ${ }^{40} \mathrm{~K}$ is the dominant $\gamma$-emitter in the ocean and in marine biota, its evaluation as a potential radioactive dose contributor is important. The dose attributable to ${ }^{40} \mathrm{~K}$ is however predominantly due to its $\beta$ emissions (UNSCEAR, 1993). ${ }^{210} \mathrm{Po}$ releases $\alpha$-particles with its decay, and $\alpha$ emissions are 20 times more damaging to cells than $\gamma$ and $\beta$ emissions (Eckerman et al., 2012). In fact ${ }^{210}$ Po has been shown as the radionuclide producing by far the greatest radioactive dose in marine biota, as it also is the greatest radioactive dose contributor to seafood consumers (Aarkrog et al., 1997). Therefore even though its radioactivity is lower, doses from the naturally occurring ${ }^{210} \mathrm{Po}$ in biota, including those from the Japanese shore (Table 1), can be of greater radiological importance than ${ }^{134+137} \mathrm{Cs}$.

\section{Summary}

This is the first report in the peer-reviewed literature on the levels of anthropogenic and natural radioactivity in the biota from coastal Japan following the Fukushima NPP failure. At the time of sample collection in June 2011, concentrations of Fukushima-derived ${ }^{137} \mathrm{Cs}$ and ${ }^{134} \mathrm{Cs}$ were elevated, and when combined (i.e., ${ }^{134+137} \mathrm{Cs}$ ) they did not exceed the $500 \mathrm{~Bq} \mathrm{~kg}^{-1}$ wet wt. recommended safety level for seafood consumption. Biota concentrations of Cs were higher in the southern locations than in the north, likely due to the 19day lag between sampling and the southward flow of coastal currents (Buesseler et al., 2012). Concentrations of individual (i.e., ${ }^{210} \mathrm{Po}$ and ${ }^{40} \mathrm{~K}$ ) natural radionuclides showed levels that were 20 -fold lower or 5-fold higher than those of ${ }^{134+137} \mathrm{Cs}$. A concentration-factor-based approach estimated that radioactive Cs concentrations in coastal waters at the northern location in the second half of June could be in the range of $2.9 \times 10^{2}-22.2 \times 10^{2} \mathrm{~Bq} \mathrm{~m}^{-3}$, and at the southern 
locations earlier on were either similar or up to 14-fold higher.

Acknowledgements. We thank J. A. George for help in collecting the samples, C. Heilbrun for technical assistance, C. WeintraubWeissman, H. Reddy, D. Li and M. Castrillejo for laboratory assistance. This project was funded by the Gordon and Betty Moore Foundation through Grant GBMF3007 to Ken Buesseler. PM was funded through the ICREA Academia prize of the Generalitat de Catalunya and the project CTM2011-15152-E of the Spanish Government

Edited by: H. Nies

\section{References}

Aarkrog, A., Baxter, M. S., Bettencourt, A. O., Bojanowski, R., Bologa, A., Charmasson, S., Cunha, I., Delfanti, R., Duran, E., Holm, E., Jeffree, R., Livingston, H. D., Mahapanyawong, S., Nies, H., Osvath, I., Pingyu, L., Povinec, P. P., Sanchez, A., Smith, J. N., and Swift, D.: A comparison of doses from ${ }^{137} \mathrm{Cs}$ and ${ }^{210}$ Po in marine food: a major international study, J. Environ. Radioactiv., 34, 69-90, doi:10.1016/0265-931x(96)000057, 1997.

Aoyama, M., Tsumune, D., Uematsu, M., Kondo, F., and Hamajima, Y.: Temporal variation of ${ }^{134} \mathrm{Cs}$ and ${ }^{137} \mathrm{Cs}$ activities in surface water at stations along the coastline near the Fukushima Dai-ichi nuclear power plant accident site, Japan, Geochem. J., 46, 321-325, 2012.

Buesseler, K., Aoyama, M., and Fukasawa, M.: Impacts of the Fukushima Nuclear Power Plants on Marine Radioactivity, Environ. Sci. Technol., 45, 9931-9935, doi:10.1021/es202816c, 2011.

Buesseler, K. O., Jayne, S. R., Fisher, N. S., Rypina, I. I., Baumann, H., Baumann, Z., Breier, C. F., Douglass, E. M., George, J., Macdonald, A. M., Miyamoto, H., Nishikawa, J., Pike, S. M., and Yoshida, S.: Fukushima-derived radionuclides in the ocean and biota off Japan, P. Natl. Acad. Sci. USA, 109, 5984-5988, doi:10.1073/pnas.1120794109, 2012.

Carvalho, F. P.: Polonium $\left({ }^{210} \mathrm{Po}\right)$ and lead $\left({ }^{210} \mathrm{~Pb}\right)$ in marine organisms and their transfer in marine food chains, J. Environ. Radioactiv., 102, 462-472, doi:10.1016/j.jenvrad.2010.10.011, 2011.

Church, T., Rigaud, S., Baskaran, M., Kumar, A., Friedrich, J., Masqué, P., Puigcorbé, V., Kim, G., Radakovitch, O., Hong, G., Choi, H.-Y., and Stewart, G.: Inter-calibration studies of ${ }^{210} \mathrm{Po}$ and ${ }^{210} \mathrm{~Pb}$ in dissolved and particulate sea water sample, Limnol. Oceanogr.-Methods, 10, 776-789, 2012.

Dahlgaard, H.: Loss of ${ }^{51} \mathrm{Cr},{ }^{54} \mathrm{Mn},{ }^{57} \mathrm{Co},{ }^{59} \mathrm{Fe},{ }^{65} \mathrm{Zn}$ and ${ }^{134} \mathrm{Cs}$ by the mussel Mytilus edulis, Impacts of Radionuclide Releases into the Marine Environment, Proceedings, Vienna, 6-10 October 1980, 361-370, Vienna, IAEA, 1981.

Dahlgaard, H. and Nolan, C.: Long-term loss rates of radioisotopes of cobalt, zinc, ruthenium, caesium and silver by Mytilus edulis under field conditions, Marine Pollution, Proceedings, Monaco, 5-9 October, 1998, 19-24, IAEA-TECDOC-1094, 1999.

Eckerman, K., Harrison, J., Menzel, H. G., and Clement, C. H.: ICRP Publication 119: Compendium of Dose Coefficients based on ICRP Publication 60, Annals of the ICRP, 41, Supplement 1, 1-130, doi:10.1016/j.icrp.2012.06.038, 2012.

Fisher, N. S., Fowler, S. W., Boisson, F., Carroll, J., Rissanen, K., Salbu, B., Sazykina, T. G., and Sjoeblom, K.L.: Radionuclide bioconcentration factors and sediment partition coefficients in Arctic seas subject to contamination from dumped nuclear wastes, Environ. Sci. Technol., 33, 1979-1982, 10.1021/es9812195, 1999.

Garnier-Laplace, J., Beaugelin-Seiller, K., and Hinton, T. G.: Fukushima wildlife dose reconstruction signals ecological consequences, Environ. Sci. Technol., 45, 5077-5078, doi:10.1021/es201637c, 2011.

Goddard, C. C. and Jupp, B. P.: The radionuclide content of seaweeds and seagrasses around the coast of Oman and the United Arab Emirates, Mar. Pollut. Bull., 42, 1411-1416, doi:10.1016/S0025-326X(01)00218-1, 2001.

Gutknecht, J.: Uptake and retention of cesium 137 and zinc 65 by seaweeds, Limnol. Oceanogr., 10, 58-66, 1965.

Hurtado, S., Villa, M., Manjón, G., and García-Tenorio, R.: A selfsufficient and general method for self-absorption correction in gamma-ray spectrometry using GEANT4, Nuclear Instruments and Methods in Physics Research Section A: Accelerators, Spectrometers, Detectors and Associated Equipment, 580, 234-237, doi:10.1016/j.nima.2007.05.090, 2007.

IAEA: Sediment distribution coefficients and concentration factors for biota in the marine environment, International Atomic Energy Agency, Vienna, 103, 2004.

Ke, C., Yu, K. N., Lam, P. K. S., and Wang, W.-X.: Uptake and depuration of cesium in the green mussel Perna viridis, Mar. Biol., 137, 567-575, doi:10.1007/s002270000373, 2000.

Kryshev, I. and Sazykina, T.: Evaluation of the irradiation dose rate for marine biota in the region of the destroyed fukushima reactor (Japan) in March-May 2011, Atom. Energy+, 111, 55-60, doi:10.1007/s10512-011-9453-x, 2011.

Masson, O., Baeza, A., Bieringer, J., Brudecki, K., Bucci, S., Cappai, M., Carvalho, F. P., Connan, O., Cosma, C., Dalheimer, A., Didier, D., Depuydt, G., De Geer, L. E., De Vismes, A., Gini, L., Groppi, F., Gudnason, K., Gurriaran, R., Hainz, D., Halldórsson, O., Hammond, D., Hanley, O., Holeý, K., Homoki, Z., Ioannidou, A., Isajenko, K., Jankovic, M., Katzlberger, C., Kettunen, M., Kierepko, R., Kontro, R., Kwakman, P. J. M., Lecomte, M., Leon Vintro, L., Leppänen, A. P., Lind, B., Lujaniene, G., Mc Ginnity, P., Mahon, C. M., Malá, H., Manenti, S., Manolopoulou, M., Mattila, A., Mauring, A., Mietelski, J. W., Møller, B., Nielsen, S. P., Nikolic, J., Overwater, R. M. W., Pálsson, S. E., Papastefanou, C., Penev, I., Pham, M. K., Povinec, P. P., Ramebäck, H., Reis, M. C., Ringer, W., Rodriguez, A., Rulík, P., Saey, P. R. J., Samsonov, V., Schlosser, C., Sgorbati, G., Silobritiene, B. V., Söderström, C., Sogni, R., Solier, L., Sonck, M., Steinhauser, G., Steinkopff, T., Steinmann, P., Stoulos, S., Sýkora, I., Todorovic, D., Tooloutalaie, N., Tositti, L., Tschiersch, J., Ugron, A., Vagena, E., Vargas, A., Wershofen, H., and Zhukova, O.: Tracking of Airborne Radionuclides from the Damaged Fukushima Dai-Ichi Nuclear Reactors by European Networks, Environ. Sci. Technol., 45, 7670-7677, doi:10.1021/es2017158, 2011.

Ministry of Agriculture, Forestry and Fisheries:Results of the inspection on radioactivity materials in fisheries products, available at http://www.jfa.maff.go.jp/e/inspection/index.html., last 
access: 5 February 2013.

Ministry of Education, Culture, Sports, Science and Technology: "Readings of marine soil monitoring in sea area" http://radioactivity.mext.go.jp/en/list/260/list-1.html.: http://radioactivity.mext.go.jp/en/list/260/list-1.html, last access: 5 February 2013.

Morita, T., Fujimoto, K., Kasai, H., Yamada, H., and Nishiuchi, K.: Temporal variations of ${ }^{90} \mathrm{Sr}$ and ${ }^{137} \mathrm{Cs}$ concentrations and the ${ }^{137} \mathrm{Cs} /{ }^{90} \mathrm{Sr}$ activity ratio in marine brown algae, Undaria pinnatifida and Laminaria longissima, collected in coastal areas of Japan, J. Environ. Monitor., 12, 1179-1186, 2010.

Murakami, M. and Oki, T.: Estimation of thyroid doses and health risks resulting from the intake of radioactive iodine in foods and drinking water by the citizens of Tokyo after the Fukushima nuclear accident, Chemosphere, 87, 1355-1360, doi:10.1016/j.chemosphere.2012.02.028, 2012.

Thompson, N., Cross, J. E., Miller, R. M., and Day, J. P.: Alpha and gamma radioactivity in Fucus vesiculosus from the Irish sea, Environ. Pollut. B, 3, 11-19, doi:10.1016/0143-148X(82)90039-8, 1982.
Tokyo Electric Power Company: News Press Releases http://www. tepco.co.jp/en/index-e.html., last access: 5 February 2013, 2013.

Tsumune, D., Tsubono, T., Aoyama, M., and Hirose, K.: Distribution of oceanic ${ }^{137} \mathrm{Cs}$ from the Fukushima Daiichi Nuclear Power Plant simulated numerically by a regional ocean model, J. Environ. Radioactiv., 111, 100-108, doi:10.1016/j.jenvrad.2011.10.007, 2011.

Uğur, A., Yener, G., and Başsarı, A.: Trace metals and ${ }^{210} \mathrm{Po}$ $\left({ }^{210} \mathrm{~Pb}\right)$ concentrations in mussels (Mytilus galloprovincialis) consumed at western Anatolia, Appl. Radiat. Isotopes, 57, 565571, doi:10.1016/S0969-8043(02)00141-0, 2002.

UNSCEAR: Report to the General Assembly, with Scientific Annexes; Annex A: Exposure from natural sources of radiation, United Nations Scientific Committee on the Effects of Atomic Radiation, 1993.

Wildgust, M. A., McDonald, P., and White, K. N.: Temporal changes of ${ }^{210} \mathrm{Po}$ in temperate coastal waters, Sci. Total Environ., 214, 1-10, doi:10.1016/S0048-9697(98)00050-3, 1998.

Yoshida, N. and Kanda, J.: Tracking the Fukushima radionuclides, Science, 336, 1115-1116, doi:10.1126/science.1219493, 2012. 